\title{
An Appraisal of Efficiency and Effectiveness of the Supreme Court of Bangladesh
}

\section{Mohammad Saiful Islam}

Doctoral fellow, School of Law,

Beijing Institute of Technology, Beijing, China \& Assistant Professor, Department of Law, International Islamic University, Chittagong (IIUC), Bangladesh

E-mail: saiful@law.iiuc.ac.bd

Type of the Paper: Research Paper.

Type of Review: Peer Reviewed.

Indexed in: OpenAIRE.

DOI: http://doi.org/10.5281/zenodo.3250674.

Google Scholar Citation: IJMTS

\section{How to Cite this Paper:}

Mohammad Saiful, Islam. (2019). An Appraisal of Efficiency and Effectiveness of the Supreme Court of Bangladesh. International Journal of Management, Technology, and Social Sciences (IJMTS), 4(1), 109-124.

DOI: http://doi.org/10.5281/zenodo.3250674.

International Journal of Management, Technology, and Social Sciences (IJMTS)

A Refereed International Journal of Srinivas University, India.

IFSIJ Journal Impact Factor for $2018=4.764$

(C) With Author.

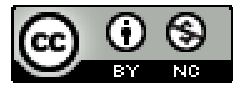

This work is licensed under a Creative Commons Attribution-Non Commercial 4.0 International License subject to proper citation to the publication source of the work.

Disclaimer: The scholarly papers as reviewed and published by the Srinivas Publications (S.P.), India are the views and opinions of their respective authors and are not the views or opinions of the SP. The SP disclaims of any harm or loss caused due to the published content to any party. 


\title{
An Appraisal of Efficiency and Effectiveness of the Supreme Court of Bangladesh
}

\author{
Mohammad Saiful Islam \\ Doctoral fellow, School of Law, \\ Beijing Institute of Technology, Beijing, China \& Assistant Professor, Department of Law, \\ International Islamic University, Chittagong (IIUC), Bangladesh \\ E-mail: saiful@law.iiuc.ac.bd
}

\begin{abstract}
The Supreme Court is the apex institution of the adjudication system and constitutional body in Bangladesh. The Constitution mandates its functions and jurisdictions. It performs functions and duties not as a servant of the government but performs constitutional functions as a guardian to uphold the Constitutionalism, secure the Constitutional guarantee of the citizens'. It has unique and extraordinary inherent jurisdictions like writ, taking action for doing complete justice, review of its own decision, punish to contemnor, settle issues arise under the Constitutional interpretation, providing perfect direction of unambiguous law, and provide advice. This paper analyzes the momentous issue of jurisdiction and functions of the Supreme Court from the legal and economic aspects with highlighting the efficiency of the apex court. It also examines with particular consideration of contempt of court matter.
\end{abstract}

Keywords: Supreme Court, Economic efficiency, Contempt of court, Constitutional law.

\section{INTRODUCTION :}

As three branches of the State; legislative enact, rescind or amending the legal rules, the executive responsible for implementing the laws, and the judiciary or judicial system applies and interprets the law in the adjudication. The Court has not empowered only for settlement of disputes among the litigants but also authorized to confirm the citizens' rights, promote the rule of law, making a sound environment for investment, and securing the economic and property rights as well. The endowed jurisdiction other than settlement of disputes particularly goes to the Supreme Court of Bangladesh that is the apex court of Bangladesh in the adjudication system. However, adjudication is a multifaceted task and applied by an established legal procedure with variable jurisdiction from court to court through a key legal institution. Judges' behaviour depends on the court system like the Supreme Court or subordinate court; hence, different court jurisdiction explores different behaviour of judges. Scholar mentioned from an economic approach that "judges like other agents will respond to the incentives created by institutions" [1]. The Supreme Courts' jurisdiction demonstrates the full range of power to exercise adjudication. Constitution places mandate that the Constitution [2] is the supreme law of the land (Art. 7) [2], and the Supreme Court is the guardian of the constitution. As a protector of the Constitution, therefore, the Supreme Court holds power to declare any legislation as null and void enacted by the legislative body or Parliament through the provision of judicial review.

The apex court is constitutional functionaries to guarantee constitutional rights and to remove error from the judgment of a subordinate court that create enormous costs on the litigation party. It can also play a large role to the development of economic growth by taking judicial action under its functions by imposing a proper sanction. Last couple of years the ruling party attempts to attainment favour through 
political appointment that makes politicization of bench. The bases of selection considering devotion to reigning out of merits mark sufficient role to settle the cases especially cases against the political opponent. The higher court bears public confidence to promote justice at any rate as an independent and constitutional body, but sometimes through the political appointment and extreme loyalty to ruling executive condense its public trust about efficiency and effectiveness of apex courts functions.

Practical implications and Value: This paper will display to the legal community a wide range of understanding about the significant issue of functions and jurisdiction of the Supreme Court. This issue has both prodigious theoretical and practical importance. In this study, some achievable recommendations have also been suggested in order to progress the efficiency and effectiveness of the Supreme Court that will reach to the policymaker to take a visible attempt to build an efficient and effective institution of adjudication. This paper holds a new dimension of research from economic aspects to understand the efficiency and effectiveness of the higher judiciary in Bangladesh that will be the attention of legal scholars, judges, law practitioners and those have interest on adjudication system of Bangladesh.

Methodology and approach: This study is mainly qualitative in nature with blending the interdisciplinary method of law and economic approach. This study has engaged the content analysis of reliable primary and secondary sources and corroborated by open-ended informal interviews with judges and Supreme Court lawyer. The content analysis covers Constitutional law, statutory law, Supreme Court rules, case law, statistical data, dependable journal articles, books, media reports, newspaper articles, and internet documents.

\section{ECONOMIC APPROACH TO COURT PERFORMERS :}

The economic approach to the court like a competitive market comprising by judges, litigants, advocates, prosecutors and government attorneys. As per economic principles, each actor as a rational human being try to maximize their utility within the limited resources. Economic principles deserve judges should deliver efficient judgment, impose proper liability to appropriate individuals, because of the wrong verdict to an innocent person or improper responsibility to the accurate person will generate a social cost. Judges try to perform and maximize their duties within constitutional constraints. Litigants attempt to get judgment in favour of him/her, advocates want to earn money and increase fame by winning litigation, prosecutor or attorney takes to attempt to get verdict in favour of government. And finally the judiciary as a legal institution should try to minimize the social costs that contain the direct costs and error costs through the effective procedures. Each actor induces by explicit or implicit incentives including ideology, money, promotion, famed, constitutional responsibility as a rational human being.

\section{CONSTITUTIONAL ARRANGEMENT OF THE SUPREME COURT :}

Bangladesh got independence twice, first attained in 1947 from the British ruling with entitled East Pakistan as a wing of Pakistan, and finally as sovereign country independence achieved in 1971 [3] after a protracted liberation war with the mass protest against the imprudent and bearish ruler of Pakistan that made a martyr of innumerable lives [4]. In 1971, after reached valuable independence Bangladesh accepted the existed law and legal institutes prior to 1971 in the part of Bangladesh [5] that was known as East Pakistan. Subsequently, the Constitution delivered "Subject to the provisions of this Constitution all existing laws shall continue to have effect but may be amended or repealed by law made under this Constitution" (Art.149) [2]. After immediate independence, the highest court in Bangladesh was the High Court set up under the High Court of Bangladesh Order1972 (Sec. 2) transmitted under the Proclamation of Independence1971 and the Provisional Constitution of Bangladesh Order1972 [6]. Afterward, Appellate Division of the High Court established by the High Court of Bangladesh (Amendment) Order 1972 that was comprised 
by the Chief Justice and other two judges of the High Court selected by the President with the discussion of Chief Justice [7]. The High Court was present till the Supreme Court of Bangladesh established under the Constitution [6]. At present, chapter I of part VI of the Constitution arrangements detail provisions regard the Supreme Court (Art. 94-113) [2]. The Constitution set up the Supreme Court, which is the apex court in the hierarchy of the judicial system, consist of two divisions, the Appellate Division (AD), and the High Court Division (HCD). The Supreme Court comprises of the Chief Justice (CJ), and such number of other judges as the President may think to appoint to each division- the AD and the HCD. The Chief Justice and the other judges of the Supreme Court shall be independent to exercise judicial functions (Art. 94) [2].

\section{EFFICIENCY AND EFFECTIVENESSOF THE SUPREME COURT :}

The Supreme Court of Bangladesh is consisting of two divisions, The AD and The HCD. The Supreme Court as a constitutional body functions, powers and jurisdictions are precisely declared in the Constitution. This paper has analyzed efficiency and effectiveness of functions of the Supreme Court that has stated in the Constitution as a jurisdiction, then explained appropriately.

\subsection{Efficiency of the Appellate Division (AD):} 4.1.1 Settlement of Appeal:

The AD hears and determines appeals of any decisions, judgments, decrees, orders or sentences of the HCD 'as of right' of the litigants or by granting a 'leave to appeal' to the $\mathrm{AD}$. It hears an appeal as of right against the HCD judgments or orders concerning to substantial question of constitutional interpretation, the death penalty, life imprisonment and contempt of court. Alternatively, all other cases for appeal shall be laid to the $\mathrm{AD}$ if only the $\mathrm{AD}$ grants leave to appeal (Art. 103) [2]. It also has the power to hear the appeal against judgments and orders of some statutory tribunals like the Administrative Appellate Tribunal and International Crimes Tribunal (ICT) etc. The parties may submit an appeal to the $\mathrm{AD}$ against an order of a sentence or an order of acquittal by the ICT as of right [8]. Its decisions are final and binding to the HCD and all courts subordinate to it (Art. 111) [2].

\subsubsection{Providing Advice to the President:}

The AD holds the authority to give advice to the President connected to any significant question of law that referred by the President under the advisory jurisdiction of the Supreme Court. According to the Constitution, the President may try to find the opinion of the $\mathrm{AD}$ at any time it appears to him any matter of the question of law has arisen or is likely to arise and which is of such nature and of such public importance it is beneficial to obtain the opinions. The AD may, after such hearing as it thinks fit, report its opinion thereon to the President (Art. 106) [2]. Although it is not compulsory to provide an advisory opinion to the President on such questions $[9,10]$, nevertheless, to giving opinion $\mathrm{AD}$ will not decline a President reference except of worthy reasons [10]. This function is not normal function, and it can appear suddenly if the President referred any serious matter concerning to substantial question of law. In this framework, two references have made to the AD in the Constitutional history. In 1995, first reference has been made to the AD for seeking its advisory opinion on the subject of boycotting of Parliament session by opposition members of Parliament (MP) for successively more than 90 days [6, 11]. In 2009 another reference was made by the President to the AD for pursuing advisory opinion concerning the adjudication method of Pill Khana Killing case [12]. Subsequently, AD took hearings by ten distinguished law specialists as Amicus Curiae [13], then, the AD made its view that this case would be suitable to decide under the ordinary criminal law, not army law [10]. The provision regards the advisory opinion of AD may meaningfully contribute to endorse good governance in the democratic system of Bangladesh. However, it is not possible to provide an advisory opinion regard with any national issue by the Supreme Court as selfmotion or while the democratic government take the path to arbitrary nature. 


\subsubsection{Exploit Complete Justice:}

The AD has observed the power of the issue and execution of the process, that also termed as power "to do complete justice", through issuing any directions, decrees, orders or writs as may be essential for achieving complete justice in any case or matter pending before it (Art. 104) [2]. This power is one of the extraordinary and discretionary of the AD, and the AD may apply this jurisdiction suomotu or on the request of any party [14]. The power of issue any order or directions to do complete justice is constituent, unique, inherent and undefined jurisdiction of the AD. The area of court jurisdiction with the term "complete justice" has defined by various case decisions in the Supreme Court of India. However, the different judgment has mentioned scope differently some in narrow, some very wide and some harmonious. The Supreme Court of India (SCI) has defined, "The phrase 'complete justice' is the word of width couched with elasticity to meet myriad situations created by human ingenuity or cause or result of the operation of statute law..." [15]. This power is supplementary in nature and applicable to any matter, proceedings pending to the court, and its completely discretionary power of the court to exercise this. In Supreme Court Bar Association $v$ Union of India \& Anr. court stated "This power is inherent to the court and is complementary to those powers which are specifically conferred on the court by various statutes though are not limited by those statutes" [16]. This power is constitutional power upon the court, and ordinary law cannot make a check to exercise this. In another case [17], the Supreme Court of India held that "This Court's power to do 'complete justice' is entire of different level and a different quality. Any prohibition or restriction contained in ordinary laws cannot act as a limitation on the constitutional power of this Court" [18]. In other judgment, court mentioned this power would exercise without making any direct conflict to the statute dealing particularly with the subject. "Indeed, these powers cannot, in any way, be controlled by any statutory provisions but at the same time, these powers are not meant to be exercised when their exercise may come directly in conflict with what has been expressly provided in a statute dealing expressly with the subject" [16]. This power is explicitly reflecting for safeguard and protective to cover that circumstance which cannot be efficiently and properly attempted through the present legal rules. In the Golaknath case, it was said that "the power is very wide and it cannot be controlled by any statutory prohibition" [19].

The AD of Supreme Court of Bangladesh conferred that in the presence of specific provisions, AD cannot invoke its inherent powers under Art. 104. The court stated that "though the Constitution has given wide power to this Division, it generally does not pass any order in contravention of or ignoring the statutory provisions..." [20]. The Court opined that this power would exercise carefully in that circumstances which cannot be appropriately and effectively endeavoured through the present law or if the current law cannot carry complete justice among the parties. The word of $\mathrm{AD}$ is "Art. 104 of the Constitution can be invoked to do complete justice only in a situation where justice cannot be effectively and appropriately dispensed with by the existing provisions of law." The AD further specified that "there is no doubt that $\mathrm{AD}$ has ample power to give such directions as are necessary for ends of justice. This power has been recognized and exercised, and this power is not restricted by statutory enactments, but it should be used sparingly" [20]. Under the inherent powers of the court, the $\mathrm{AD}$ makes such orders as may be required for the ends of justice or to prevent abuse of the process of the court (Order XXXIV, rule 8) [21]. This provision is legal tools conferred on the court in case of inadequacy of legal requirements, or the court thinks that there is a panorama of substantial injustice to the party, AD should implement its inherent power to prevent injustice and to minimize the error in the judicial decisions. This inherent power cannot constraint by the statutory law because this has vested through the constitutional power on the court. As said by the Constitutional duty the Supreme Court is the guardian and protector of the citizen's rights and is entrusted for exploit justice among the litigant parties. Why the 
Constitution separately mentioned about to issue any decree or order to do complete justice. For the reason that, the $\mathrm{AD}$ division is the last stage for settlement of the case, final phase to do confirm justice, to guarantee fundamental rights of citizens, to uphold the life, liberty, and to maintain constitutionalism in the country.

The economic approach to the judicial procedure is settlement the disputes efficient and effective way and minimize the social costs that comprising by direct costs, error costs and also by indirect costs. Economic attitude to the judicial system is not to increase the direct cost to reduce the error cost, but decrease both prices are the ultimate target. The error in the subordinate court judgments can remove through the Supreme Court, and AD is the last place to do this. If in this stage $\mathrm{AD}$ is failed to remove the error in the decisions, social costs will generate on the party and in the society. An error may be occurred through imposing punishment or liability to the improper individual or imposing penalty or liability to the proper person with inappropriate amount. If the highest court cannot reduce the error, the negative incentive will create to the litigants and the court will lose the trust regarding disputes settlement. For example, suppose $\mathrm{X}$ is convicted by the subordinate court for the wrong amount of sentences like life imprisonment or wrong amount of liability, and $\mathrm{AD}$ is also failed to remove this amount by judicial process, then, this will be a cause of social costs. Sometimes this failure of proper verdict causes for poverty for the reason that, the convicted person has already spent a lot of money for the judicial process, lost the job for inattentive in the job place to being present in the court or person detained in the jail. The period of staying as detainee has an opportunity cost. So, in the stage of proceedings of $\mathrm{AD}$ court abundantly required to the power of review, the power to do complete justice among the litigant parties. Hence, these constitutional provisions are economically efficient to do confirm justice and prevent to injustice.

\subsubsection{Review of Judgments or Orders:}

The decisions of AD are final, even though it can alter or modify its own judgements through review under exceptional situations [9]. The Constitution declared "The Appellate Division shall have power, subject to the provisions of any Act of Parliament and of any rules made by that division to review any judgment pronounced or order made by it" (Art. 105) [2]. The power of review is the inherent power of the $\mathrm{AD}$, and this Division can exercise this inherent power to do justice. In the review stage, AD generally doesn't make a major change of its judgments. The following significant cases have reviewed by $\mathrm{AD}$ like 5th amendment case, and particularly decisions in case of the death penalty under the 'international crimes tribunal'. In the matter of war crimes tribunal case primarily the prosecution from the government argued that convicted persons have not right to apply for review to the AD. Afterward, this complexity has removed by the decision on Abdul Quader Mollah's review application. In that review, AD said that a convicted person could file a petition for review against the decision of $\mathrm{AD}$ but accept or reject the review petition is absolute power of the AD. The AD stated "no prohibition either expressly or by implication to move a review petition from the judgment of this Division on appeal from the judgment of the Tribunal" [20]. The Court further stated in the same judgment, "If a party is affected by an order or judgment of the court, in the absence of specific provision for review, the court has inherent power to review its order or judgment" [20]. The Court also said "It is now established that inherent powers of the court can be exercised by a court of law at any stage of the proceedings." "The court can use its inherent powers to fill up the lacuna left by the legislature while enacting law or where the legislature is unable to foresee any circumstance which may arise in a particular case" [20]. The primary function of the court is to establish justice between the parties, and this phase of adjudication proceeding is almost final stage for a convicted person to get access of justice, for free and fair trial proceedings, and correction of an error of the court order. The error in the judgment generates a sufficient cost on the litigant and on the society that is economically not efficient. The ultimate target of judicial 
procedure as of economic approach is to minimize social costs that include error costs also. In the absence of specific provision, the court may exercise power to review if wrong or an error identified in its judgment. The court mentioned, "The appellate authority has the power to review the entire materials on record subject to limitations prescribed" [20]. AD also delivered "securing ends of justice a review is maintainable in the exercise of the inherent powers of this Division subject to the condition that where the error is so apparent and patent that review is necessary to avoid a miscarriage of justice" [20].

When the law doesn't contain certain provisions, the court acts by inherent power along with equity, justice and good conscience to reach of justice or to preclude the abuse of the procedure of the court. The AD stated in Quader Mollahcase "The appellate court cannot invoke its inherent power if it finds necessary to meet the ends of justice or to prevent the abuse of the process of the court", and court further mentioned "In an appeal entire proceedings are before the appellate authority, and it has the power to review the entire materials on record subject to limitations prescribed" $[20,22]$. The Supreme Court is the guardian of the citizen's rights, and $\mathrm{AD}$ has the constitutional duty to ensure the justice among the parties, therefore, in respect of upholding the justice for all $\mathrm{AD}$ should fully enjoy this power. Correspondingly the Appellate Division Rules mentioned "The $\mathrm{AD}$ may, either of its own motion or on the application of a party to a proceeding, review its judgment or order in a Civil proceeding on grounds similar to those mentioned in Order XLVII, rule 1 of the Code of Civil Procedure and in a Criminal proceeding on the ground of an error apparent on the face of the record" (Order XXVI, rule 1) [21]. Following AD rules the review petitions shall file within thirty days.

\subsubsection{Execution of Rule-making Functions:}

The AD enjoys rules-making power for regulating its practice and procedure or of the HCD, and any court subordinate to it [23] subject to the law made by Parliament with the approval of the President [24]. The rules making power is constitutional power of the Supreme
Court for governing its own procedures and also for court subordinate to it. We have observed, however, a long time court hearing and taking time over and over again by the government from the Supreme Court for determining rules regarding 'discipline of lower court judges' as per the direction of the Masdar Hossain case, well-known as the separation of judiciary case. At present, according to the Constitutional provision, the powers of control and disciplinary matter about subordinate court judges are conferred on the president with the consultation of the Supreme Court (Art.116) [2]. By pleasing this opportunity, for own unending technique of control of the executive upon judges of lower court, the government made draft as per their pleasure not conforming with the direction of Supreme Court, and the Supreme Court rejects the draft for further amending. At the time of Chief Justice S. K. Sinha (when he was Chief Justice) the Supreme Court expressed their grievances against the negligence of the government to formulate gazette of the rules. Finally, after historic resignation of Justice S. K. Sinha, Chief Justice at that time, the government has prepared the disciplinary rules with the consensus of Supreme Court and the government, then it published through official gazette on 11 December 2017 by naming "Bangladesh Judicial Service (Disciplinary) Rules 2017”. Subsequently, in line with these rules, the Chief Justice shall determine and constitute benches of AD and HCD with ascertaining which judges are to be seated for what purpose (Art. 107) [2]. This rulemaking functions are ultimately under the control and influence of both other two organs namely legislative and executive by imposing two constraints. Firstly, regulations framed by the Supreme Court are subject to the law made by Parliament. Secondly, the rules made by the Supreme Court must attain the approval of the President to be effective [25].

\subsubsection{Proceedings for Contempt of Court:}

The Constitution remarks $\mathrm{AD}$ is a court of record and shall have all the powers of such a court including the power to make an order for the investigation or punishment for any contempt of itself or of the HCD (Art. 108) [2, 
26]. It is exceedingly established principle in the judicial system that 'court of record' has the power to punish for contempt. In 1867 C. J. Sir Barnes Peacock laid down "there can be no doubt that every court of record has the power of summarily punishing for contempt" [27]. Jowitt's Dictionary of English Law defined a 'Court of Record means' "A Court whereof the acts and judicial proceedings are enrolled for a perpetual memory and testimony, and which has power to fine and imprison for contempt of its authority" [28]. The power to punish for contempt of court is inherent power of the court as a Court of record, then legislation that reduces or curtail Supreme Court's inherent and constitutional power is invalid [29]. The AD may take cognizance of its contempt suomotuor on a petition by any person (Order XXVII, rule 1) $[21]$.

\subsection{Efficiency of the High Court Division (HCD):}

The power and functions of the HCD determine by the two sources, like constitutional law and ordinary law. The HCD, therefore, exercises functions to adjudicate disputes under original, appellate, revisional and other jurisdiction conferred to it by the Constitution or any other statutory law (Art. 101) [2, 30]. The court practices and procedures are guided by the Supreme Court (High Court Division) Rules 1973.

\subsubsection{Exercising Original Power:}

Under the original jurisdiction besides the writ petition (special original jurisdiction), the HCD can proceeds a suit as a court of first instance that particularly mentioned in the ordinary law. As per its original jurisdiction HCD hears cases connecting to contempt of court [31], company issues [32], admiralty matters [33], patent [34], trademarks [35], will and probate [36], certain matrimonial issues of the Christian religion [37], problems concerning banking companies [38], and disputes of Parliamentary elections [39]. The HCD as a Constitutional court exercises jurisdiction over the constitutional interpretation, the conformity of constitutionality of executive orders, judicial decisions and legislation enacted by Parliament. The HCD has meaningfully implemented the power concerning to determination of the constitutionality of legislative act and executive orders. For example, it declares significant amendments of constitution containing $5^{\text {th }}, 7^{\text {th }}, 8^{\text {th }}, 13^{\text {th }}$, and $16^{\text {th }}$ constitutional amendment as ultra vires. It also has the power to the application of constitutional guarantees and legal obligations. Under this jurisdiction, the HCD is authorized to issue directions and orders to implement constitutional rights of the citizens in the form of writs of prohibition, mandamus, certiorari, habeas corpus and quowarranto (Art. 102) [2].

4.2.2 Hearing Appeal, Revision, Review and Transfer of Cases:

The HCD hears appeals against judgments, decrees and orders of subordinate courts. Any law may deliberate appellate jurisdiction on the HCD on any matter such as The Code of Civil Procedure, 1908; The Code of Criminal Procedure, 1898; Section 42 of Value Added Tax Act, 1991; Section 196D of the Customs Act, 1969 etc. and the High Court Division Rules 1973 have deliberated appellate jurisdiction on the HCD. The HCD has empowered with review [40] and revisional power [41]. It holds power to inspect the decisions of the courts subordinate to it. Moreover, under section 561A of the Code of Criminal Procedure, the HCD has inherent authority to deliver such order as may be needed to confirm any direction under this Code or to preclude abuse of the procedure of any court or else to sheltered the ends of justice. It has also reference [42] jurisdiction to provide an opinion or order on a particular case referred by any subordinate lower court. It has the power to withdraw any case [43] from subordinate courts to itself after satisfying that cases are involved with the substantial question of constitutional interpretation or matter of general public importance, and, then resolve the case by itself, or send to the that subordinate court where from the case was quiet or transfer to any other subordinate court after determining the question (Art. 110) [2]. The law declared by the HCD of the Supreme Court shall be binding on all courts subordinate to it (Art. 111) [2].

\subsubsection{Performing Supervisory Power:}

The HCD has supervisory power regard 
superintendence and control of all subordinate courts and tribunals (Art. 109) [2]. It is a constitutional supervisory power. Besides this, CPC and CrPC have also conferred power upon the HCD to control subordinate courts [44] that's called statutory supervisory power. Statutory supervisory powers cover to judicial matters but not to administrative matters, whereas the Constitutional supervisory powers include supervision both administrative and judicial matters [45]. This power is discretionary power, and then no one can invoke as of right although the HCD can apply it Suo Motu or by an application of a party. The legislation can reduce the statutory supervisory powers, but the constitutional supervisory power cannot curtail without an amendment of the Constitution [46]. However, in Art. 116 of the Constitution [47] indicated vis-à-vis control of the judges of subordinate court including promotion, discipline, posting, and leave shall vest on the President, and shall be exercised with the consultation of Supreme Court. As per Art 109 of the Constitution the HCD is authorized to supervise, administer and control all subordinate court. Lusciously it was reflecting in the Art.115 and 116 of the original and unamended Constitution of 1972 through empowering the Supreme Court to appoint, posting, promotion and to control the subordinate judges by following words "Appointments of persons to offices in the judicial service .... President in that behalf after consulting the appropriate public service commission and the Supreme Court" (Art.115). And "The control (including the power of posting, promotion and grant of leave) and discipline of persons employed in the judicial service and magistrates exercising judicial functions shall vest in the Supreme Court" (Art. 116). But by the Fourth Amendment of the Constitution 1975, all powers captured by the President and eradicated the power of the Supreme Court. Subsequently, the judiciary faces de facto full executive control and acts to oblige "the political interests of the ruling executive rather than acting as an independent judicial organ of the Republic" [48]. On 11 December 2017 after one decade of separation of judiciary finally the government issued the gazette notification of service and disciplinary rules for lower courts judges with the heading "Bangladesh Judicial Service (Disciplinary) Rules 2017”. However, despite the AD's directions, all power regarding control and disciplinary matters of lower courts judges has retained under the control of the President. In the gazette sub-rules 8 of rule 2 describes competent authority as the President or the ministry or division entrusted within the scope of the Rules of Business framed under section 55(6) of the Constitution [49].

After the separation of judiciary, in 2007, it was highly required that Supreme Court will be empowered to administer and control the lower courts as per 12 points guiding principle counting guideline for the creation of service rules and code of conduct for lower court judges given by the $\mathrm{AD}$ in the historic verdict of State $\mathrm{V}$ Masdar Hossain on $2^{\text {nd }}$ December 1999 [50]. Afterward, in July 2011 the government introduced the manner of 'consultation' with the Supreme Court regard control and discipline of lower court judges by amending the Art.116 of the Constitution in the fifteenth amendment of the Constitution which states: "The control (including the power of posting, promotion and grant of leave) and discipline of persons employed in the judicial service ...... shall vest in the President and shall be exercised by him in consultation with the Supreme Court" (Art. 116) [2]. The term 'Consultation' in the Art.116 doesn't convey the merely lexicographic, formal or unproductive consultation, but the interpretation concentrates the effects of Articles 109 and 116A absolutely, for the reason that, without control upon the presiding judges' control and superintendence by the Supreme Court over the subordinate courts cannot be effective. Executive control over subordinate judges by the government cannot confirm their independence. Art. 116, therefore, must be interpreted and read along with the provisions under Art.109 and 116A [25]. Once the consultation with the Supreme Court treated as only formal and unproductive apparently this is a duel standard of supervision and control of the subordinate judiciary. This is a 'duel standard' process for the reason that Art. 109 provide 
HCD is authorized to administer and control the subordinate court, on the other side as per Art. 116 the control of lower court judges is on the President's hands. Though the High Court is the authorized to monitor and control the lower courts judges along the lines of a convention since 1861 , and that was a replica in the original unamended constitution in 1972. Recently the government has enacted new disciplinary rules for lower courts judges by keeping control of the President that eventually devoted to the Law Ministry. Still, as stated by Art. 48 (3) of the Constitution, the President performs activities on the advice of the prime minister that promote the abundant government space to take control over the lower judiciary. If the all authority vis-à-vis controls of lower courts judges place to the law ministry, then the question is arising about the supervisory power or necessity of the High Court itself, then that at the end contradictory with the arrangement of independence of the judiciary. It is a method of impeding of the judicial functions then result is growing miseries to justice- seekers since the Supreme Court cannot proceed anything concerning to lower courts judges including promotion, transfer or any disciplinary steps caused by the current Art.116. At this time, though, it is truthfully discoursed that regarding the monitoring of subordinate judiciary power has exercised by the executive of the government in the name of President [51]. Therefore, the HCD doesn't have an effective opportunity to perform constitutional power about control of subordinate judiciary from the administrative side. From the aspect of law and economics politicians and bureaucrats make afford to maximize their utility from the subordinate court through keeping control of posting, promotion, leave and others.

\subsubsection{Exercise the Power as Court of Record:}

The HCD also is a court of record and has the constitutional authority to punish any person for committing contempt of court either itself or of others court subordinate to it (Art. 108) [2, 52]. In the judgment of the Supreme Court held that there is no opportunity for any argument that the HCD has the power to punish summarily for contempt of court as Higher Courts of record that is inherent jurisdiction. It is not mandated of a statute but an inherent event of each court of record. This inherent jurisdiction, therefore, cannot be wiped out [29].

\section{EFFICIENCY OF THE SUPREME COURT CONCERNING CONTEMPT OF COURT :}

Judiciary, as a significant organ of the State, is treated as the fundamental institution of a democratic country to uphold the citizens' rights, constitutionalism, to support good governance and has sufficient role to economic growth. From the Constitutional spirit to the general people and litigants the Supreme Court is the place of trustworthiness and reliability to getting justice. If anybody doesn't get a remedy at anywhere his ultimate target go to the Supreme Court and he believes that court will not discard about his claim. Contempt of court or stated simply as 'contempt' is "the offense of being disobedient to or discourteous toward a court of law and its officers in the form of behaviour that opposes or defies the authority, justice and dignity of the court" [53]. Contempt of court can be either in civil nature or in criminal nature. Contempt of court in civil nature includes wilful noncompliance to the judgments, decree, orders, any process of the court, or disobedience of the court order to do or refrain from doing, or the break of any responsibility prearranged to the court. On the other side criminal contempt comprises disgraces to judge in open court, deter persons to presence court, defamations on judges; courts or court officers, bad comments in court or on the decisions of the court, making disruption in court, and any publication which insults the dignity of the court [54].

A person is said in contempt of court for showing disobedient or disrespectful concerning any order or decision of the court; fail to comply the court order or to give a statement about the court that is harmful to the dignity of the court. As per constitutional arrangement subordinate court is a fragment of the judiciary. Hence, any contemptuous attitude in oral, action or broadcast concentrating to the subordinate courts will extend to harm to the entire judicial 
institution. Thus, the HCD division has jurisdiction to punish for contempt of subordinate courts. The Supreme Court has been empowered to investigate and punish against contempt itself by the Constitutional power, then the last couple of years Supreme Court has attempted to punish of many solid cases. Although Art.108 of the Constitution has authorized the Supreme Court about this power. Similarly, the government has enacted 'the Contempt of Court Act 2013' [55] changing the old law of 1926 for punishing contempt of the court. However, the High Court division has declared provisions of clauses $4,5,6,7,9,10$, 11 and 13 (2) of this Act is invalid and unconstitutional. The court has detected that this law decreases the constitutional powers of the Supreme Court and also conflicting to the Constitution's Art. 27, 108 and 112 for the reason that it offered government officials and journalists more protection from other citizens [56].The Supreme Court has also provided several directions regard contempt of court matter. This paper places devotion on most significant contempt cases proceeding by the Supreme Court in the last couple of years.

\subsection{Mahmudur Rahman Case:}

The AD has imposed a sentence to $\mathrm{Mr}$. Mahmudur [57] for six months of imprisonment with fine Tk. 0.1 million [58] (around 1,130 Euros) with confirming "gross contempt of court" against him for having issued a report in his editing daily on 21 April, 2010 under the caption "Chamber maneisarkarpakkhe stay" (Chamber bench means stay order in favor of the government) [59]. In the $\mathrm{AD}$ proceedings, this was the first time convicted and sentenced somebody for contempt of court in the history of the judiciary. In the same petition, the $\mathrm{AD}$ has settled that proceedings through imposing sentence two other respondents [60] for contempt of court concerning their obligation in respect of the publication of that report. However, the AD has released two other respondents [61] from the charge in this case after expressing their regret to the court unconditionally. The Court has sentenced to protect the image of the judiciary, to sustain public confidence in the system and to secure the administration of justice stated in the verdict [62]. In the same year, Mr. Mahmudur has convicted with contempt of court for the second time by the Apex Court. The court has delivered punishment [63] him for fine Tk. 100 (without any custodial punishment), and in the event of avoidance the fine he will have to jail for one day's simple imprisonment. The AD said in verdict that accused has scandalized the court by way of such commentary, and committed contempt of court. The court, however, held it has taken the substance compassionately [64].The court, however, didn't mention the reasons for proceeding this case caringly while the contemnor had punished first time for six months' imprisonment in the same year.

\subsection{Two Ministers Case:}

The Apex Court has convinced with allegation [65] of contempt of court against two sitting ministers [66] then has imposed fine them for Tk. 50,000 each for scandalization of the superior court of the country. The contemnors had commended regard the matter of sub judice including Chief Justice at that time. They had remarked that the Chief Justice should take back himself from the appeal hearing of Mir Quasem Ali's death sentence that earlier delivered by the International Crimes Tribunal (ICT), Bangladesh by claiming of committing war crimes throughout the liberation war of the country. The ministers demanded this unusual request for the reason that the Chief Justice had apparently uttered dissatisfaction to the investigation and prosecution of the Tribunal vis-à-vis Quasem Ali's case. The Court considered that the contemnors have purposefully made this utterance and their comments are "derogatory and highly contemptuous." The court further measured that the comments and speeches are scandalous interference to "the administration of justice, questioning the independence of the judiciary, undermined the public confidence, dignity; prestige and authority and impartiality of the Supreme Court" [67]. In the last one decade many significant contempt cases have been settled through the Supreme Court that affirmed 'scandalization' to a great extent form of contempt of court, then it has substantial consequences on the litigants and the court 
concern individuals. It is apparently clear that the ultimate reason for punishment of contempt of court is to uphold the judicial dignity, maintain public confidence to get justice and to secure the administration of justice. The court held that ".... convicted and sentenced the contemnors to set an example and to give caution to all that it has become a fashion to criticize the judges for no fault of them" [67]. However, the legal scholar has claimed that the reason providing to scandalization as a slice of contempt of court have been less conclusive [68, 69]. An economic approach to law is an incentive and making prices to individual behaviour, hence the economic analysis of punishment of contempt of court generates a price to contemnors, therefore litigating party, interested people to court procedure, press and media, and political leaders would be cautious to occurring the contempt of court. The less tolerance of contempt of court by the country's Apex court and imposing exemplary punishment in last one decade including media and government personnel create awareness among the court concern people that ultimately reduce the matter of contempt freshly.

\section{FINDINGS AND CONCLUSION :}

The significant findings-in line with the Constitutional arrangement the Supreme Court is the guardian of the Constitution and protector of the constitutional rights of citizens'. It grips some unique and extraordinary inherent jurisdictions like writ, taking action for doing complete justice, review power of its own decision, punish to contemnor for contempt of court, make clear of unambiguous law, provide advice to the president in the matter of Constitutional or substantial issue. The Supreme Court has abundantly played a role against the contempt of court by imposing imprisonment and monetary punishment. Conversely, major problems identify that more political appointment influences on the hearing predominantly in the political involvement cases. The Supreme Court is the last resort for getting justice and remove error of judgment through adjudication. It exercises some surprising functions as a constitutional body to uphold the Constitution. The advisory jurisdiction is the unique power of the $\mathrm{AD}$ that indicates the accurate direction from uncertainty of the interpretation of the law. By this power, the apex court can contribute to developing the actual benevolent democratic country. It's conditional, however, to demand by the President to the Supreme Court. The power to do complete justice is an extraordinary and inherent jurisdiction of the $\mathrm{AD}$ that has been entrusted the apex court to take any initiative or effort to secure ultimate justice. The AD would apply this open-ended jurisdiction with actively since the passivism in this phase may happen large volume of injustice and may generate a massive social cost upon the society that is the insignia of inefficient of the judiciary. The special original jurisdiction of the HCD is scimitar to remove state barriers to endorse constitutional guarantee of citizens' that should settle without delay. The Court would settle petition independently without of fear and affection to anybody or political power for the sake of independent and faith of judiciary. In recent years, it is sorrowfulness that judiciary destroying trust, faith and public confidence upon the higher adjudication institution even there has been growing grievance over the honesty of particular action that judges too frequently with partialities intensely favouring ruling executive in respect of political cases.

\section{REFERENCES :}

[1] Kornhauser, L. A. (2012). 11 Judicial organization and administration. In C. W. Sanchirico \& S. A. Blank (Eds.), Procedural Law and Economics, Encyclopedia of Law and Economics (Second ed., Vol. 8 pp. 308-340): Edward Elgar Publishing Limited.

[2] The Constitution of the People's Republic of Bangladesh was accepted through the Constituent Assembly on 4 November 1972, and came into effect on 16 December 1972, which was the first anniversary of the independence of Bangladesh. Till 2018, There are seventeen amendments of the constitutions. The last amendment was made by 17 th amendment in 2018 regard expansion of women reserved fifty seats in the parliament for the period of next 
twenty-five years (hereafter The Constitution of the Bangladesh, 1972), Bangladesh Code.

[3] The Proclamation of Independence Order, 10 April of 1971, effected from 26 March 1971.

[4] The specification about the amount of martyr is highly tricky and research identified within variable numbers. But among the people wellknown amount is three million approximately. See Isalāma, S. a. A. m., Haque, I., Khan, S. I., Islam, S. A., \& Haque, M. I. (2008). Political culture, political parties and the democratic transition in Bangladesh. Dhaka, Bangladesh: Academic.

[5] The Laws Continuance Enforcement Order 1971, came into effect from 26 March 1971.

[6] Akkas, S. A. (2004). Independence and Accountability of Judiciary: A Critical Review: Centre for Rights and Governance.

[7] The High Court of Bangladesh (Amendment) Order 1972, section 3.

[8] The International Crimes (Tribunals) Act 1973, section 21(1); (2). In this Act convicted person can appeal against his conviction and sentence, and the complainant or the government or the informant can appeal against an order of acquittal or order of any amount of sentence. Interestingly, in this Act initially, there had no opportunity of appeal from the government side in order of acquittal or of sentencing. After pronouncing the judgment of Quader Mollah's case (as of life imprisonment) by war crimes tribunal the government made an amendment of this Act in 2013, then insertion the provision of appeal for the government side giving retrospective effect from 14th July 2009 and this was the first appeal to the $\mathrm{AD}$ by the government under this Act.

[9] Hoque, R. (2014). Courts and the Adjudication System in Bangladesh: In Quest of Viable Reforms. In J.-r. Yeh \& W.-C. Chang (Eds.), Asian Courts in Context (pp. 447-486): Cambridge University Press.

[10] Panday, P. K., \& Hossain Mollah, A. (2011). The judicial system of Bangladesh: an overview from historical viewpoint.
International Journal of Law and Management, 53(1), 6-31.

[11] Constitutional Reference No. 1 of 1995 III (BLT) (1995) (Spl.) 159.

[12] This historic case is also well known by ' $B D R$ revolt case', 'Pill Khana tragedy case', 'BDR carnage case' etc.

[13] The Supreme Court has selected ten senior lawyers as amici curiae to make an opinion on this reference. They are Dr Kamal Hossain, Rafique-ul Haque, TH Khan, Amir-ul-Islam, Mahmudul Islam, Khandaker Mahbubuddin Ahmed, Rokanuddin Mahmud, Ajmalul Hossain, ASM Mesbahuddin and A F Hassan Ariff. Retrieved from https:/bdnews24.com/bangladesh/2009/08/25/a micus-curiae-opposes-military-trial on 20/12/2018.

[14] Halim, M. A. 2008a. The Legal System of Bangladesh, Dhaka, Bangladesh: CCB Foundation, Dhaka, p. 89.

[15] Ashok Kumar Gupta, Vidya Sagar ... v State of U.P. \& Others [1997] 5 SCC 201 (SCI).

[16] Supreme Court Bar Association v Union of India \& Anr.[1998] 4 SCC 409 (SCI).

[17]Delhi Judicial Service Association v State of Gujarat [1991] AIR 2176; 3 SCR 936 (SCI).

[18] This explanation was agreed by the Constitution Bench in the case of Union Carbide Corporation v. Union of India [1990] AIR 273; [1989] 2 SCC 540.

[19] Golaknath v State of Punjab [1967] AIR 1643; 2 SCR 762 (SCI).

[20] Abdul Quader Mollah $v$ The Chief Prosecutor, International Crimes Tribunal, Dhaka, Criminal Review Petition Nos. 17-18 of 2013, 3 LNJ (AD) (2014) 121.

[21] The Supreme Court of Bangladesh (Appellate Division) Rules 1988.In:1358/2007 SC (AD). Dhaka, Bangladesh: Supreme Court of Bangladesh.

[22] The similar opinion has observed by the Supreme Court of India in the case of Shiv Shakti Coop. Housing v. M/s. Swaraj 
Developers, Civil Appeal No.3489 of 2003 [2003] 6 SCC 659 (SCI).

[23] Md. Masdar Hossain and Others $v$ Bangladesh 18 (1998) (BLD) HCD 558.

[24] As a result, the Supreme Court of Bangladesh has made rules for governing its procedures namely "The Supreme Court of Bangladesh (Appellate Division) Rules 1988" and "The Supreme Court of Bangladesh (High Court Division) Rules 1973”.

[25] Ahmed, J. N. (1998). The Problem of Independence of the Judiciary in Bangladesh Bangladesh Journal of Law, 2(2), 134-151.

[26] The AD has settled numerous contempt of court petitions in the last couple of years with penalty including in Md. Riaz Uddin Khan, Advocate and another $v$ Mahmudur Rahman and others 63 DLR (AD) (2011) 29; The State v Advocate Qamrul Islam and Another (2016) (AD) Contempt Petition(A) 9/2016; Advocate Riazuddin Khan v Mahmudur Rahman (2010) 9 AD Cases 140; and The State $v$ Swadesh Roy (2015) 12 App. Div. Cases. 932.

[27] In Re Abdool and Mahtab [1867] 8 W.R. Cr. 32. Calcutta High Court.

[28] Jowitt's. (Ed.) (2015) Jowitt's Dictionary of English Law (4 ed.). UK: Sweet \& Maxwell.

[29] Dr.Mohiuddin Khan Alamgir Vs. Sohul Hossain. 1 SCOB [2015] HCD 28.

[30]There are a number of other statutory laws which deliberate jurisdiction to the HCD for settling disputes. The main ordinary laws are the Code of Civil Procedure 1908, and The Code of Criminal Procedure 1898.

[31] The Contempt of Court Act 1926, section 2. However, in 2013 the government enacted a new law of contempt of court, but the HCD has declared some provisions as illegal. See for details "HC revokes Contempt of Courts Act", Dhaka Tribune, 26 September 2013. Retrieved from

https://www.dhakatribune.com/uncategorized/20 $13 / 09 / 26 /$ hc-revokes-contempt-of-courts-act on 25/12/2018.

[32] The Companies Act 1994, section 3.
[33] The Admiralty Court Act 2000, section 3.

[34] The Patents and Designs Act 1911.

[35] The Trademarks Act 2009.

[36] The Succession Act 1925.

[37] The Divorce Act 1869.

[38] The Banking Company Act 1991.

[39] The Representation of the People Order (RPO) 1972, Art. 49.

[40] Section 114 of The Code of Civil Procedure 1908. The procedure of review deals under Part II, Chapter X of the High Court Division Rules 1973 and Order XLVII of the Code of Civil Procedure 1908.

[41] Section 115 of The Code of Civil Procedure 1908 and Section 439 of The Code of Criminal Procedure 1898.

[42] Section 113 of The Code of Civil Procedure 1908 and Section 435 of The Code of Criminal Procedure 1898 have arranged the reference jurisdiction on the HCD to provide opinion and direction on a case referred to it by any subordinate Court. The HCD is also empowered to hear income tax references under section 160 of Income Tax Ordinance 1984.

[43] Section 24 of the Code of Civil Procedure 1908 and section 526 of the Code of Criminal Procedure 1898.

[44] Section 115 of The Code of Civil Procedure 1908 and section 435, 436, 439, 491 of The Code of Criminal Procedure 1898.

[45] A.T. Mirdha V. State 25 DLR 335.

[46] Halim, M. A. 2008b. Constitution, constitutional law and politics: Bangladesh perspective ( $4^{\text {th }}$ ed.),Dhaka: CCB Foundation, $\mathrm{p}$. 96.

[47] For interpretation and implication of Article 116, See Aftabuddin v Bangladesh 48 (1996) DLR HCD 1.

[48] Islam, M. R., \& Solaiman, S. (2003). Public Confidence Crisis in the Judiciary and Judicial Accountability in Bangladesh. Journal of Judicial Administration, 13, 29-60. 
[49] See for details 'Judges' service rules gazette published, lower courts still in President's hands", Dhaka Tribune, 11 December 2017. Retrieved from https://www.dhakatribune.com/bangladesh/lawrights/2017/12/11/gazette-lower-court-judgesservice-rules/ on 20/12/2018.

[50] State v Masdar Hossain, 52 DLR (AD) 82; 20 BLD (AD) 104.

[51] Islam, M. R. (2017). The Judiciary of Bangladesh. In H. P. Lee \& M. Pittard (Eds.), Asia-Pacific Judiciaries (1 ${ }^{\text {st }}$ ed., pp. 35-56): Cambridge University Press.

[52] The HCD has been taken in their proceedings numerous petitions for contempt of court itself. The most significant cases in the last couple of years like the HCD punished the joint editor of daily Prothom Alo in 2014; highly condemn of former govt. secretary Asafuddowla; and Dr. Mohiuddin Khan Alamgir Vs. Sohul Hossain in 2010, 1 SCOB [2015] HCD 28 etc.

[53] Oxford. (Ed.) (2017) English Oxford Living Dictionaries (Online ed.). Oxford University Press.

[54] Ahmed, T. N. (February 27th, 2018). Striking a balance between contempt and freedom of speech, Opinion. Dhaka Tribune. Retrieved from https://www.dhakatribune.com/opinion/oped/2018/02/27/striking-balance-contemptfreedom-speech on 10/02/2019.

[55] The Contempt of Court Act 2013 enacted on 22 February 2013, Act no. IV of 2013, Bangladesh Code.

[56] For details, Dhaka Tribune, 26 September 2013. Retrieved from https://www.dhakatribune.com/uncategorized/20 13/09/26/hc-revokes-contempt-of-courts-act on 25/12/2018.

[57] Mahmudur Rahman is acting editor of daily Amar Desh, popular Bangla daily in Bangladesh. Finally, Amar Desh was shut down by the government in 2013. The verdict delivered by the AD on 19 August 2010.

[58] In case of nonpayment of this amount he will have to detain extra one more month in jail, the court had ordered.

[59] The petition about contempt of court filed to the court on 2 May 2010 by two lawyers of Supreme Court-Riaz Uddin Khan and Mynul Hassan, stated to be devotees of the Government-against Mahmudur Rahman and four other journalists of the daily Amar Desh for publishing that report. Subsequently, on June 2 the court delivered a contempt of court rule against Mr. Rahman and the four. For details 'SC slams on contempt', The Daily Star, 20 August 2010. Retrieved from https://www.thedailystar.net/news-detail-151450 on $25 / 12 / 2018$.

[60] Mr. Waliullah Noman, special correspondent of Amar Desh, was punished for one month's imprisonment and fine Taka 10,000 and extra seven days' jail order in case of nonpayment of the fine, and Mr. Hashmat Ali, the publisher of the daily Amar Desh, was also fined Taka 10,000 in nonpayment of this fine he has to serve imprisonment for seven days.

[61] Mr. Syed Abdal Ahmed, deputy editor of daily Amar Desh, and Mr. Mujtahid Faruqui, news editor of daily Amar Desh.

[62] Md. Riaz Uddin Khan, Advocate and another Vs. Mahmudur Rahman and others. 63 DLR (AD) (2011) 29; 19 BLT (AD) (2011) 54; 16 MLR (AD) (2011) 161.

[63] The AD, led by Chief Justice ABM Khairul Haque, declared judgement on 11 October 2010 for publishing commentary report titled "Swadhin bicharer name tamasa" (farce in the name of fair trial) in his edited daily on 10 May 2010 after hearing a contempt of court petition that was filed by two pro-government Supreme Court lawyers-Reaz Uddin Khan and Kazi Mynul Hassan. In this petition, the court acquitted Hasmat Ali, publisher of the daily Amar Desh, from the contempt charge.

[64] Advocate Riazuddin Khan v. Mahmudur Rahman. 9 Appellate Division Cases 140.

[65] On $6^{\text {th }}$ March 2016 the Daily Jugantor, one popular national Bengali daily of Bangladesh, published details report of comments made by 
two sitting Ministers of the Government about the matter under hearing of the $\mathrm{AD}$ at a roundtable discussion held at Bangladesh Institute of Law and International Affairs (BILIA) Auditorium, Dhaka, then, Attorney General made an attention of the highest court regarding the report. Hence on $8^{\text {th }}$ March 2016 the Apex Court issued the notice to show cause them on or before $14^{\text {th }}$ March 2016.

[66] Advocate Md. Qamrul Islam, M.P., Minister of Food, and Mr. A.K.M. Mozammel Huq, M.P., Minister of Liberation War Affairs, Government of the People's Republic of Bangladesh.

[67] The State $v$ Advocate Qamrul Islam and Another (2016) (AD), Contempt Petition(A) 9/2016.

[68] Siddiq, E. A. (2018). Scandalizing the court and the law of contempt In C. I. A. Siddiky (Ed.), The Rule of Law in Developing Countries: The Case of Bangladesh (1 ed.). New York: Routledge.

[69] Siddiq, E. A. (2016). The State v. Advocate Md. Qamrul Islam and Another (2016). University of Asia Pacific Journal of Law \& Policy, 2(1), 59-65. 